\title{
Kontribusi Minat Baca dan Hubungan Sosial Terhadap Kompetensi Pengetahuan IPS pada Siswa Kelas V
}

\author{
Ni Made Treismayanti ${ }^{1}$, I Wayan Sujana ${ }^{2}$, Ni Wayan Suniasih ${ }^{3}$ \\ Prodi Pendidikan Dasar, Universitas Pendidikan Ganesha, Singaraja, Indonesia \\ e-mail: ni.made.treismayanti@undiksha.ac.id ${ }^{1}$, iwayan.sujana@undiksha.ac.id ${ }^{2}$, \\ niwayan.suniasih@undiksha.ac.id ${ }^{3}$
}

\begin{abstract}
Abstrak
Penelitian ini bertujuan untuk mengetahui pengaruh yang signifikan minat baca dan hubungan sosial terhadap kompetensi pengetahuan IPS pada siswa kelas V SD Gugus Dewi Sartika Kecamatan Denpasar Selatan dan besaran kontribusinya. Penelitian ini menggunakan rancangan ex post facto dengan pendekatan korelasional. Populasi dalam penelitian ini adalah seluruh siswa kelas $\mathrm{V}$ di SD Gugus Dewi Sartika yang berjumlah 250 orang. Sampel pada penelitian ini ada 152 orang yang ditentukan dari populasi menggunakan teknik proportional random sampling. Metode pengumpulan data menggunakan teknik non tes dengan instrumen dalam bentuk angket yang terdiri dari 30 pernyataan untuk pengambilan data minat baca dan hubungan sosial. Sebelum angket diujicobakan dilakukan uji instrumen dengan uji validitas konstruk, uji validitas butir dan uji reliabilitas. Data kompetensi pengetahuan IPS diperoleh dengan teknik pencatatan dokumen. Data hasil penelitian yang telah memenuhi uji prasyarat analisis di uji menggunakan analisis statistik inferensial dengan teknik analisis regresi ganda. Hasil penelitian menunjukkan $F_{\text {hitung }}=4,6>F_{\text {tabel }}=3,06$ berdasarkan kriteria hal ini menunjukkan terdapat pengaruh yang signifikan antara minat baca dan hubungan sosial terhadap kompetensi pengetahuan IPS dengan kontribusi sebesar 5,9\%. Maka dapat disimpulkan bahwa minat baca dan hubungan sosial memberikan kontribusi sebesar $5,9 \%$ terhadap kompetensi pengetahuan IPS pada siswa kelas V SD Gugus Dewi Sartika Kecamatan Denpasar Selatan. Sehingga $94,1 \%$ lainnya dipengaruhi oleh faktor belajar lain baik dari faktor dalam diri maupun faktor dari luar diri siswa.
\end{abstract}

Kata Kunci : hubungan sosial, kompetensi, minat baca

\begin{abstract}
This study aimed to determine the effect of reading interest and social relations on social science competency in fifth grade students of SD Gugus Dewi Sartika Denpasar Selatan District and the amount of contribution. This study used an ex post facto design with a correlational approach. The populations in this study were all of the fifth grade students in SD Gugus Dewi Sartika which numbered 250 students. The samples in this study were 152 students that were determined from the population using proportional random sampling technique. The method of data collection using nontest techniques with instruments in the form of questionnaires consisting of 30 statements for data retrieval of reading interest and social relations. Before the questionnaire was tested, the instrument was tested by construct validity test, item validity test and reliability test. Social Science knowledge competency data is obtained by the document recording technique. The data from research results that have met the analysis prerequisite test were tested using inferential statistical analysis with multiple regression techniques. The results show $F_{\text {count }}=4,63>\quad F_{\text {table }}=3,06$ which is based on criteria there is significant effect between reading interest and social relations with Social Science knowledge competencies with a contribute around 5,9\%. Then it can be concluded that reading interest and social relations contribute around $5.9 \%$ to the competency of Social Science knowledge in fifth grade students of SD Gugus Dewi Sartika, Denpasar Selatan District. So that the other $94.1 \%$ are influenced by other learning factors from both internal and external factors.
\end{abstract}

Keywords: social relation, competency, reading interest 


\section{Pendahuluan}

Sebuah negara dikatakan maju apabila negara tersebut memiliki Sumber Daya Manusia yang berkualitas. Upaya untuk meningkatkan kualitas sumber daya manusia, harus diimbangi dengan peningkatan mutu pendidikan. Peningkatan mutu pendidikan dapat membantu mewujudkan cita-cita bangsa yaitu mencerdaskan kehidupan bangsa. Terwujudnya sistem pendidikan sebagai pranata sosial yang kuat dan berwibawa memberdayakan semua warga negara Indonesia berkembang menjadi manusia yang berkualitas sehingga mampu dan proaktif menjawab tantangan zaman yang selalu berubah (Undang-Undang Nomor 20 Tahun 2003).

Kurikulum 2013 sebagai wajah baru pendidikan di Indonesia memang memberikan banyak perubahan pada kegiatan belajar baik dari konsep, buku, proses pembelajaran itu sendiri sampai pada penilaiannya. Namun, hanya dengan menyempurnakan salah satu aspek dalam pendidikan saja tidak akan mampu menyempurnakan pendidikan di Indonesia. Masalah yang timbul dalam dunia pendidikan untuk membangun Sumber Daya Manusia yang berkualitas juga bisa terjadi saat kegiatan pembelajaran berlangsung. Potensi yang dimiliki peserta didik dan guru sebagai fasilitator bahkan sarana dan prasarana saat proses pembelajaran berlangsung juga memengaruhi suatu proses pembelajaran. Kegiatan pembelajaran itu sendiri merupakan suatu sistem yang dilalui untuk mencapai keberhasilan dalam belajar. Keberhasilan dalam belajar pada kurikulum 2013 disebut kompetensi. Sesuai dengan tujuan pendidikan yang mengharapkan terwujudnya manusia yang memiliki potensi dalam diri dan memiliki keterampilan dalam bermasyarakat berbangsa dan bernegara, maka pada kurikulum 2013 kompetensi yang membantu terwujudnya hal tersebut adalah kompetensi pengetahuan IPS.

Kompetensi Pengetahuan IPS adalah keberhasilan siswa dalam proses belajar yang banyak melibatkan ilmu-ilmu sosial mengenai kehidupan bermasyarakat. Permendikbud Nomor 21 Tahun 2016 tentang Standar Isi menjelaskan "ruang lingkup dari IPS itu sendiri meliputi: (1) manusia, tempat dan lingkungan; (2) waktu, keberlanjutan dan perubahan; (3) sistem sosial dan budaya serta (4) perilaku ekonomi dan kesejahteraan". Permendikbud Nomor 57 Tahun 2014 Tentang Kurikulum 2013 Sekolah Dasar/Madrasah Ibtidaiyah menyatakan bahwa "mata pelajaran IPS bertujuan untuk menghasilkan warga negara yang religius, jujur, demokratis, kreatif, kritis, senang membaca, memiliki kemampuan belajar, rasa ingin tahu, peduli dengan lingkungan sosial dan fisik, berkontribusi terhadap pengembangan kehidupan sosial dan budaya, serta berkomunikasi secara produktif". IImu pengetahuan sosial dapat diperoleh melalui sumber pengetahuan. Salah satu sumber dari pengetahuan adalah buku. Muatan materi pelajaran yang dipaparkan saat pembelajaran pada ilmu pengetahuan sosial banyak tertuang dalam buku, karenanya siswa diharapkan rajin membaca agar dapat mencapai target keberhasilan pembelajaran.

Kurikulum 2013 yang menyajikan pembelajaran secara tematik mengaitkan mata pelajaran satu dan lainnya dengan muatan Bahasa Indonesia sebagai pengantar. Muatan IPS biasanya akan tertuang dalam bahan bacaan Bahasa Indonesia. Guru memberikan masalah, siswa ditugaskan menemukan sendiri dari bahan bacaan yang sudah tersedia kemudian berdiskusi bersama-sama untuk menemukan jawaban dari permasalahn yang ada. Kegiatan membaca yang dilakukan siswa menjadi penting karena pengumpulan informasi berlangsung di dalamnya dan terkumpulnya informasi akan membantu siswa memecahkan masalah yang ada. Terpecahkannya masalah dapat menjadi acuan guru dalam mengetahui pencapaian Kompetensi Pengetahuan IPS siswa.

Harapan akan tercapainya pembelajaran yang berpusat pada siswa dengan keaktifan siswa mencari pengetahuan khususnya dalam Kompetensi Pengetahuan IPS ternyata tidak berlangsung sesuai harapan. Penemuan ketika melaksanakan kegiatan PPL-Real di salah satu sekolah dasar di Denpasar, terdapat kondisi dimana masih banyak siswa yang kurang mengindahkan perintah guru dalam pembelajaran maupun dalam kegiatan literasi. Siswa cenderung lebih banyak berbincang-bincang dengan teman dari pada memusatkan diri pada kegiatan pembelajaran. Saat siswa ditugaskan menyampaikan informasi yang diperolehnya 
setelah kegiatan membaca, ditemukan hanya beberapa siswa yang sanggup dan mau menyampaikan pendapat atas kemauannya sendiri.

Sedikitnya siswa yang bersedia membaca buku dan menyampaikan pendapat dalam pembelajaran menunjukan belum optimalnya minat siswa dalam membaca buku. Minat merupakan salah satu faktor yang muncul dari dalam diri selain kecerdasan dan motivasi. Sudarsana (2014:1.12) mengungkapkan "Minat baca merupakan kekuatan yang mendorong seseorang untuk memperhatikan, merasa tertarik, dan senang terhadap aktivitas membaca sehingga mereka mau melakukan aktivitas membaca dengan kemauan sendiri". Dengan membaca yang dilakukan secara rutin dan tanpa dorongan dari orang lain khususnya pada buku pelajaran tentunya akan menambah wawasan dan pengetahuan yang dimiliki siswa sehingga membantunya dalam mencapai target keberhasilan.

Pasifnya kegiatan diskusi di dalam kelas, kurangnya keaktifan siswa saat bertanya maupun menyuarakan pendapat saat pembelajaran berlangsung, cara siswa berkomunikasi dengan sesama atau dengan guru dan kelompok pertemanan siswa yang masih cenderung berteman dengan orang yang sama (homogen) merupakan masalah-masalah yang timbul dalam kompetensi pengetahuan IPS karena kurangnya hubungan sosial siswa. Walgito (dalam Candra, 2016:181) menyatakan, "hubungan sosial atau interaksi sosial adalah hubungan antara individu yang satu dengan yang lainnya, individu yang satu dapat mempengaruhi individu yang lainnya atau sebaliknya, dalam hal ini terjadi hubungan yang timbal balik. Hubungan tersebut dapat terjadi antara individu dengan individu, individu dengan kelompok atau kelompok dengan kelompok". Dengan adanya masalah-masalah seperti yang dipaparkan maka hubungan sosial siswa harus dimaksimalkan agar siswa memiliki hubungan yang baik dengan teman maupun dengan guru, dapat aktif menyuarakan pendapatnya dan berteman dengan siapa saja. Dengan maksimalnya hubungan sosial siswa diharapkan mampu meningkatkan target pencapaian keberhasilan siswa dalam pembelajaran.

Meningkatkan Kompetensi pengetahuan IPS siswa disekolah dipicu oleh faktor dari dalam diri dan faktor dari luar diri yang harus diperhatikan, dalam hal ini adalah minat baca dan hubungan sosial. Beranjak dari kedua faktor yang mempengaruhi kompetensi pengetahuan IPS tersebut, dilakukan penelitian untuk mengetahui kontribusi minat baca dan hubungan sosial terhadap kompetensi pengetahuan IPS. Penelitian ini berjudul "Kontribusi Minat Baca dan Hubungan Sosial terhadap Kompetensi Pengetahuan IPS Pada Siswa Kelas V SD Gugus Dewi Sartika Kecamatan Denpasar Selatan".

Fokus penelitian ini dari berbagai permasalahan yang melatarbelakangi, dibatasi pada siswa mudah bosan saat membaca, siswa kurang mendengarkan intruksi guru, siswa kurang terlibat aktif dalam diskusi, dan pertemanan siswa yang kurang heterogen sehingga menyebabkan kurang maksimalnya kompetensi pengetahuan IPS pada Siswa Kelas V SD Gugus Dewi Sartika Kecamatan Denpasar Selatan.

Penelitian ini bertujuan untuk mengetahui pengaruh minat baca terhadap kompetensi pengetahuan IPS pada siswa kelas V SD Gugus Dewi Sartika Kecamatan Denpasar Selatan, pengaruh hubungan sosial terhadap kompetensi pengetahuan IPS pada siswa kelas V SD Gugus Dewi Sartika Kecamatan Denpasar Selatan dan pengaruh minat baca dan hubungan sosial secara bersama-sama terhadap kompetensi pengetahuan IPS pada siswa kelas V SD Gugus Dewi Sartika Kecamatan Denpasar Selatan. Apabila terdapat pengaruh yang signifikan, maka dilanjutkan menghitung besaran kontrribusi variabel bebas terhadap variabel terikat.

\section{Metode Penelitian}

Penelitian ini bertujuan untuk mengetahui besaran kontribusi minat baca dan hubungan sosial terhadap kompetensi pengetahuan IPS dengan tidak melakukan manipulasi variabel bebas sehingga tergolong penelitian ex post facto dengan pendekatan korelasional. Tempat dilaksanakannya penelitian ini adalah pada siswa Kelas V SD Gugus Dewi Sartika, Kecamatan Denpasar Selatan, Provinsi Bali yang terdiri dari 4 sekolah yaitu, SD Negeri 3 
Pedungan, SD Negeri 6 Pedungan, SD Negeri 11 Pedungan dan SD Negeri 13 Pedungan. Penelitian ini dilaksanakan di SD Gugus Dewi Sartika karena kemudahan akses dan kelayakan. Kemudahan akses yang dimaksud adalah lokasi sekolah yang berada di kota sehingga memudahkan akses peneliti karena data untuk variabel juga akan lebih banyak jika dibandingkan dengan sekolah yang aksesnya kurang terjangkau. Kelayakan yang dimaksud adalah belum pernah dilakukan penelitian yang sama di SD Gugus Dewi Sartika.

Kecamatan Denpasar Selatan dan didukung dengan lingkungan sekolah yang kondusif.Penelitian ini melibatkan variabel bebas dan variabel terikat. Adapun variabel bebas dalam penelitian ini disebut juga sebagai variabel prediktor. Variabel prediktor dalam penelitian ini adalah minat baca dan hubungan sosial, karena akan mempengaruhi variabel terikat yaitu kompetensi pengetahuan IPS.

Populasi dalam penelitian ini adalah 250 orang yang merupakan seluruh siswa kelas $\mathrm{V}$ SD Gugus Dewi Sartika Kecamatan Denpasar Selatan yang terdiri dari 4 sekolah dasar negeri dengan jumlah keseluruhan 8 kelas. Sampel berjumlah 152 orang ditentukan dengan menggunakan tabel issac and michael dengan melihat pada tabel sesuai dengan jumlah populasi 250 orang. Pengambilan sampel dalam penelitian menggunakan teknik proporsional random sampling yang artinya pengambilan sampel yang dilakukan menurut banyaknya populasi dari setiap kelas secara acak tanpa memperhatikan strata yang ada dimana setiap populasi memiliki hak yang sama berdasarkan nilai probabilitas dan dapat dilakukan dengan cara undian.

Pengumpulan data dalam penelitian di kelas V SD Gugus Dewi Sartika ini menggunakan metode nontes. Kegunaan metode non tes adalah untuk mengumpulkan data yang tidak dapat dikumpulkan dengan teknik tes berupa sikap, tingkah laku, sifat, sikap sosial dan sejenisnya. Metode non tes yang digunakan untuk mengumpulkan data dalam penelitian ini adalah kuesioner/angket dan pencatatan dokumen. Pengumpulan data untuk data variabel terikat yakni kompetensi pengetahuan IPS menggunakan metode pencatatan dokumen. Metode nontes berupa kuesioner/angket dalam penelitian ini digunakan untuk mengumpulkan data variabel bebas yaitu minat baca dan hubungan social.

Kuesioner minat baca dan hubungan sosial dalam penelitian ini terdiri dari 30 butir pernyataan yang sebelumnya dilakukan uji instrumen dengan validitas konstruk yaitu validitas konstruk digunakan untuk mengukur instrumen yang telah disusun berdasarkan teori tertentu yang dikonsultasikan kepada ahli materi (judgement experts). Uji validitas butir, yaitu cara mengukur ketepatan yang dimiliki oleh setiap butir dari keseluruhan butir yang ada. Valid tidaknya suatu tes sangat ditentukan oleh validitas yang dimiliki oleh masingmasing butir tes. Uji reliabilitas adalah uji yang mencerminkan ketepatan instrumen penelitian yang digunakan dalam mengukur dan menggali informasi yang diperlukan.

Skala yang digunakan untuk mengukur skor minat baca dan hubungan sosial adalah skala likert. Jawaban disetiap item instrumen yang menggunakan skala likert mempunyai gradasi dari sangat positif sampai sangat negatif, yang berupa kata-kata sangat setuju, setuju, tidak setuju, sangat tidak setuju. Bentuk kuesioner yang digunakan dalam penelitian ini adalah kuesioner tetutup. Pada kuesioner dalam bentuk tertutup jawaban yang ditulis oleh subjek penelitian lebih dibatasi sesuai dengan pertanyaan dan permintaan yang ada. Bentuknya disusun dengan memuat pernyataan positif dan pernyataan negatif. Pernyataan positif adalah pernyataan yang mendukung komponen variabel bebas, sedangkan pernyataan negatif adalah pernyataan yang tidak mendukung variabel bebas. Hal ini diberikan untuk memperkecil kecenderungan responden dalam memilih pada salah satu kategori. Kuesioner minat baca dibuat dengan memperhatikan indikator yaitu (1) kesenangan membaca, (2) dorongan membaca, (3) kesadaran akan manfaat membaca, (4) frekuensi dan ketersediaan waktu membaca, (5) kuantitas sumber bacaan. Indikator yang digunakan untuk membuat kuesioner hubungan sosial adalah (1) percakapan, (2) saling pengertian, (3) kerjasama, (4) keterbukaan, (5) empati, (6) dukungan, (7) rasa positif, (8) kesetaraan. 
Sedangkan data kompetensi pengetahuan IPS yang diperoleh adalah data interval yang didapatkan dengan pencatatan dokumen hasil ujian akhir semester I siswa kelas V SD Gugus Dewi Sartika kecamatan Denpasar Selatan.

Sebelum diuji analisis data yang diperoleh terlebih dahulu di uji dengan 4 uji prasyarat yang meliputi (1) uji normalitas residual. Uji Normalitas dilakukan untuk mengetahui sebaran residu data minat baca, hubungan sosial dan skor kompetensi pengetahuan IPS siswa berdistribusi normal atau tidak. (2) Uji linieritas, uji ini dilakukan untuk mengetahui bentuk hubungan linier antara masing-masing variabel bebas dengan variabel terikat. (3) Uji multikolinieritas, uji multikoinearitas dilakukan untuk menguji ada atau tidaknya korelasi antara variabel bebas dalam model regresi ganda. Analisis regresi yang baik disyaratkan tidak terjadi multikolinearitas diantara variabel bebasnya. (3) Uji heteroskedastisitas, uji ini bertujuan untuk menguji apakah dalam model regresi terjadi ketidaksamaan varians dari residual suatu pengamatan ke pengamatan yang lain. Model regresi yang baik adalah yang tidak terjadi heteroskedastisitas.

Setelah semua syarat terpenuhi dilanjutkan dengan menguji hipoptesis dengan analisis regrersi sederhana dan regresi ganda. Hipotesis yang diuji dalam penelitian ini adalah $\mathrm{H}_{0}$ yang berbunyi (1) tidak terdapat pengaruh yang signifikan minat baca terhadap kompetensi pengetahuan IPS pada siswa kelas V SD Gugus Dewi Sartika Kecamatan Denpasar Selatan, (2) tidak terdapat pengaruh yang signifikan hubungan sosial terhadap kompetensi pengetahuan IPS pada siswa kelas V SD Gugus Dewi Sartika Kecamatan Denpasar Selatan dan (3) tidak terdapat pengaruh yang signifikan minat baca dan hubungan sosial terhadap kompetensi pengetahuan IPS pada siswa kelas V SD Gugus Dewi Sartika Kecamatan Denpasar Selatan.

\section{Hasil dan Pembahasan}

Data Kompetensi Pengetahuan IPS siswa diperoleh melalui pencatatan dokumen berupa nilai akhir semester I atas persetujuan dari masing-masing guru wali kielas V SD di Gugus Dewi Sartika Kecamatan Denpasar Selatan. Sesuai dengan jumlah responden yang digunakan dalam penelitian, pencatatan dokumen untuk Kompetensi Pengetahuan IPS siswa dilakukan pada 152 orang responden. Data hasil Kompetensi Pengetahuan IPS siswa disajikan dalam bentuk tabel.

Data hasil minat baca dan hubungan sosial pada siswa kelas V SD di Gugus Dewi Sartika Kecamatan Denpasar Selatan pada penelitian ini diperoleh setelah melakukan penyebaran angket minat baca dan hubungan sosial pada 152 orang responden dengan pernyataan yang berjumlah 30 butir soal dengan 4 pilihan jawaban berdasarkan atas skala likert. Hasil pengujian data yang telah diteliti sebelumnya ditemukan sebagai berikut.

Uji prasyarat pertama adalah uji normalitas. Uji ini digunakan untuk mengetahui residual data penelitian terdistribusi normal atau tidak. Kriteria pengujian normalitas residu adalah nilai $\| \mathrm{F}_{\mathrm{T}}-\mathrm{F}_{\mathrm{S}} \mid$ terbesar < Nilai Tabel Kolmogorov, maka data terdistribusi normal. Data hasil uji normalitas residual minat baca terhadap kompetensi pengetahuan IPS menunjukkan nilai $\left\|\mathrm{F}_{\mathrm{T}}-\mathrm{F}_{\mathrm{S}}\right\|$ terbesar $=0,041<$ Nilai Tabel Kolmogorov-Smirnov $=0,110$ maka residu data minat baca terhadap kompetensi pengetahuan IPS terdistribusi normal. Data hasil uji normalitas residual hubungan sosial terhadap kompetensi pengetahuan IPS menunjukkan nilai $\left|\mathrm{F}_{\mathrm{T}}-\mathrm{F}_{\mathrm{S}}\right|$ terbesar $=0,053<$ Nilai Tabel Kolmogorov-Smirnov $=0,110$ maka residual data hubungan sosial terhadap kompetensi pengetahuan IPS terdistribusi normal. Data hasil uji normalitas residual minat baca dan hubungan sosial terhadap kompetensi pengetahuan IPS menunjukkan nilai $\| \mathrm{F}_{\mathrm{T}}-\mathrm{F}_{\mathrm{S}} \mid$ terbesar $=0,040<$ Nilai Tabel Kolmogorov-Smirnov $=0,110$ maka residual data minat baca dan hubungan sosial terhadap kompetensi pengetahuan IPS terdistribusi normal.

Nilai residual data juga dapat dilihat dengan propgram SPSS 24,0 for windows dengan kriteria pada nilai tabel asymp. sig.(2-talled) lebih dari nilai $\alpha=0,05$ maka nilai residu terdistribusi normal. Hasil uji normalitas residual data penelitian minat baca terhadap kompetensi pengetahuan IPS, hubungan sosial terhadap kompetensi pengetahuan IPS dan 
secara bersama-sama minat baca dan hubungan sosial terhadap kompetensi pengetahuan IPS dengan spss memperoleh nilai asymp. sig.(2-talled) sebesar 0,200. Nilai yang diperoleh ini lebih besar dari taraf signifikansi sebesar 0,05 sehingga dapat disimpulkan bahwa nilai residual data terdistribusi secara normal.

Uji Prasyarat analisis yang kedua adalah uji linieritas menggunakan tabel analysis of varians (ANAVA), melalui tabel ANAVA dapat diketahui secara bersamaa nilai linieritas dan signifikansinya. Adapun kriteria pengujian syarat linieritas yaitu $F_{\text {hitung }} \leq F_{\text {tabel }}$ maka linier dan kriteria uji signifikansi yaitu $F_{\text {hitung }}>F_{\text {tabel }}$ dengan taraf signifikansi yang sama $5 \%$ maka signifikan. Data hasil uji linieritas penelitian ini diperoleh minat baca dan kompetensi pengetahuan IPS $F_{\text {hitung }}=1,102<\mathrm{F}_{\text {tabel }}=1,51$ pada taraf signifikan $5 \%$ maka data minat baca terhadap kompetensi pengetahuan IPS memiliki hubungan yang linier. Dan $\mathrm{F}_{\text {hitung }}=$ $5,704>\mathrm{F}_{\text {tabel }}=3,9$ pada taraf signifikan $5 \%$ maka signifikan. Hasil uji linieritas data hubungan sosial dan kompetensi pengetahuan IPS memperoleh hasil $F_{\text {hitung }}=1,174<F_{\text {tabel }}$ tabel $=1,51$ pada taraf signifikan $5 \%$ maka data hubungan sosial terhadap kompetensi pengetahuan IPS linier. Dan $F_{\text {hitung }}=7,294>F_{\text {tabel }}=3,9$ pada taraf signifikan $5 \%$ maka data juga signifikan.

Uji Prasyarat ketiga adalah uji multikolinieritas, uji ini menggunakan program spss 24.0 for windows dengan kriteria uji pada nilai melihat nilai Variance Inflation Factor (VIF) dan Tolerance, apabila nilai VIF kurang dari 10 dan Tolerance lebih dari 0,1 maka dinyatakan tidak terjadi multikoliniearitas. Hasil uji multikolinieritas pada variabel minat baca dan hubungan sosial terhadap kompetensi pengetahuan IPS secara terpisah, sama-sama menghasilkan nilai Tolerance $=0,819$ dan $V I F=1,221$, nilai ini telah memenuhi kriteria tolerance lebih dari 0,1 dan VIF kurang dari 10, maka tidak terjadi multikolinieritas antara variabel bebasnya.

Uji Heteroskedastisitas adalah uji prasyarat ke empat yang dilakukan dengan program SPSS 24.0 for windows menggunakan perhitungan uji glejser. Adapun kriteria uji adalah nilai signifikansi antara variabel independen dengan nilai absolut residual lebih dari 0,05 maka tidak terjadi masalah heteroskedastisitas. Hasil nilai signifikansi penelitian ini menunjukkan angka minat baca $=0,284$ dan hubungan sosial $=0,053$ keduanya lebih dari 0,05 maka memenuhi kriteria uji yang berarti tidak terjadi heteroskedastisistas pada model regresi. Setelah dilakukian uji prasyarat dan data telah memenuhi ke 4 uji prasyarat tersebut maka pengujian dilanjutkan dengan uji hipotesis pertama dan kedua menggunakan analisis regresi sederhana dan hipotesis ke tiga menggunakan analisis regresi ganda.

Uji hipotesis pertama yang menyatakan tidak terdapat pengaruh yang signifikan minat baca terhadap kompetensi pengetahuan IPS pada siswa kelas V SD Gugus Dewi Sartika Kecamatan Denpasar Selatan ditolak dengan persamaan regresi yang diperoleh $\widehat{Y}=19,091$ $+0,338 \mathrm{X}$ linier dan signifikan. Persamaan ini menunjukkan setiap kenaikan 1 kali satuan minat baca akan menyebabkan kenaikan sebesar 0,338 nilai kompetensi pengetahuan IPS pada konstanta 19,091. Hasil analisis data memperoleh koefisien determinasi $R^{2}=0,037$. Hal ini menunjukkan terdapat pengaruh yang signifikan minat baca terhadap kompetensi pengetahuan IPS pada siswa kelas V SD Gugus Dewi Sartika Kecamatan Denpasar Selatan dengan kontribusi sebesar 3,7\%.

Rendahnya kontribusi minat baca terhadap kompetensi pengetahuan IPS, selain dipengaruhi oleh faktor dalam diri dan faktor luar diri lainnya juga dikarenakan sulit menggambarkan spesifikasi dari minat baca. Minat baca adalah keinginan seseorang untuk membaca yang masih bersifat sangat umum. Minat baca seseorang tidak bisa diukur hanya dengan menyukai satu jenis buku saja, sehingga meskipun dalam penelitian ini sudah diarahkan pada minat baca dalam buku pelajaran masih banyak juga yang memiliki kesukaan membaca pada buku-buku selain buku pelajaran seperti komik dan novel. Hal ini tentunya mempengaruhi besaran kontribusi minat baca terhadap kompetensi pengetahuan IPS.

Hasil Hipotesis kedua pada uji regresi sederhana pengaruh Hubungan Sosial $\left(\mathrm{X}_{2}\right)$ dengan Kompetensi Pengetahuan IPS (Y) pada siswa kelas V SD Gugus Dewi Sartika Kecamatan Denpasar Selatan memperoleh persamaan regresi sebesar persamaan regresi 
$\widehat{Y}=14,295+0,398 X$ signifikan dan linier. Persamaan ini menunjukkan setiap kenaikan 1 kali satuan hubungan sosial akan menyebabkan kenaikan sebesar 0,398 pada nilai kompetensi pengetahuan IPS siswa pada konstanta 14,295, sehingga $\mathrm{H}_{0}$ yang menyatakan tidak terdapat pengaruh yang signifikan hubungan sosial terhadap kompetensi pengetahuan IPS pada siswa kelas V SD Gugus Dewi Sartika Kecamatan Denpasar Selatan ditolak dengan koefisien determinasi $R^{2}=0,046$. Hal ini menunjukkan terdapat pengaruh yang signifikan hubungan sosial terhadap kompetensi pengetahuan IPS pada siswa kelas V SD Gugus Dewi Sartika Kecamatan Denpasar Selatan dengan kontribusi sebesar 4,6\%.

Hasil Hipotesis ketiga pada uji regresi ganda diperoleh persamaan $\widehat{Y}=2,330+0,215 X+$ $0,302 X$ yang signifikan. Persamaan ini menunjukkan bahwa setiap kenaikan 1 kali satuan minat baca dan 1 kali satuan hubungan sosial akan menyebabkan kenaikan 0,215 minat baca dan 0,302 hubungan sosial nilai kompetensi pengetahuan IPS pada konstanta 2,330 sehingga $\mathrm{H}_{0}$ yang menyatakan tidak terdapat pengaruh yang signifikan minat baca dan hubungan sosial terhadap kompetensi pengetahuan IPS pada siswa kelas V SD Gugus Dewi Sartika Kecamatan Denpasar Selatan ditolak dengan kontribusi sebesar 5,9\%.

Berdasarkan hasil penelitian kontribusi minat baca dan hubungan sosial terhadap kompetensi pengetahuan IPS menunjukkan terdapat pengaruh yang signifikan minat baca dan hubungan sosial terhadap kompetensi pengetahuan IPS pada siswa kelas V SD Gugus Dewi Sartika Kecamatan Denpasar Selatan sebesar 5,9\%. Sedangkan sisanya 94,1\% lainnya dipengaruhi oleh faktor belajar lainnya baik dari dalam diri berupa motivasi belajar, motivasi berprestasi, kecerdasan interpersonal, kecerdasan emosional, kecerdasan naturalis, konsep diri, disiplin belajar, sikap tanggungjawab, sikap kompetitif dan lain-lain serta faktor dari luar diri seperti fasilitas belajar, lingkungan pertemanan, gaya belajar, status anak dalam keluarga, pola asuh orang tua, bimbingan belajar, status ekonomi keluarga, lingkungan belajar dan kurikulum.

Kompetensi Pengetahuan IPS adalah perubahan tingkah laku seseorang yang dapat dilihat melalui jenjang kemampuan berfikir meliputi mengingat (remember), memahami/mengerti (understand), menggunakan/menerapkan (apply), menganalisis (analyze), menilai (evaluate), dan dimensi pengetahuannya terbatas fakta (factual) dan konsep (conceptual) tentang kehidupan masyarakat dan lingkungan. Kompetensi pengetahuan IPS adalah salah satu kompetensi yang harus dicapai siswa melalui kegiatan belajar. Djaali (2014:99) mengungkapkan bahwa "belajar dipengaruhi oleh faktor dari dalam diri dan faktor dari luar diri”. Salah satu faktor dari dalam diri disebutkan adalah minat. Minat adalah dorongan atau rasa lebih suka terhadap suatu hal tanpa ada yang menyuruh. Salah satu minat yang dapat membantu dalam pencapaian keberhasilan siswa dalam belajar adalah minat baca.

Minat baca merupakan salah satu faktor dalam diri siswa yang mempengaruhi kompetensi pengetahuan IPS siswa. Minat baca adalah keinginan seseorang untuk membaca buku demi memperoleh informasi tanpa adanya paksaan dan dengan sadar meluangkan waktu khusus untuk membaca atas kemauannya sendiri. Minat baca dapat juga dikatakan suatu kebiasaan yang menjadi sebuah kebutuhan. Minat baca siswa yang yang tinggi akan menambah wawasan dan pengetahuan siswa. Siswa yang memiliki minat baca yang tinggi akan meluangkan waktunya untuk membaca buku-buku pelajaran. Ada dorongan dari dalam dirinya atas kemauan sendiri mengumpulkan informasi berupa pengetahuan dengan cara membaca buku sehingga siswa akan memiliki pandangan dan wawasan yang luas. Dengan pengetahuan dan pandangan yang luas akan suatu hal akan membantu siswa dalam melihat masalah dari berbagai sudut pandang sehingga ketika didalam kelas ketika guru memberikan masalah yang harus diselesaikan, siswa dapat melihat masalah dari berbagai sudut pandang sehingga dapat memecahkan masalah-masalah tersebut dengan kreatif. Hasil penelitian ini sejalan dengan penelitian yang dilakukan oleh Sari (2016) yang membuktikan bahwa minat baca memiliki hubungan yang signifikan dengan hasil belajar IPS siswa dengan besar nilai korelasi 0,633 dengan tingkat korelasi kuat (rhitung 0,633 > rtabel $0,195)$ dengan besarnya persentase hubungan minat baca dan hasil belajar IPS yaitu sebesar $40,06 \%$. 
Hubungan sosial atau interaksi sosial adalah sebuah kegiatan atau tindakan yang terjadi antara individu dengan individu lainya, individu dengan kelompok atau kelompok dengan kelompok yang melibatkan hubungan timbal balik. Tiga hal penting dalam hubungan sosial adalah aksi, interaksi dan transaksi. Hubungan sosial adalah salah satu faktor dari luar diri seseorang yang mempengaruhi kompetensi pengetahuan IPS siswa. Melalui hubungan sosial siswa mampu beradaptasi dengan baik dengan teman-teman dan guru serta dapat mengemukakan pendapatnya dengan baik. siswa yang memiliki hubungan sosial yang baik akan aktif ikut serta dalam diskusi saat pembelajaran berlangsung sehingga dapat meningkatkan pencapaian dalam suatu pembelajaran. Hasil penelitian ini juga sejalan dengan penelitian yang dilakukan oleh Listriana (2016) yang menunjukkan bahwa terdapat hubungan yang signifikan antara interaksi sosial dengan hasil belajar IPS siswa, ditunjukkan dengan harga rhitung sebesar 0,624, sedangkan rtabel dengan jumlah $\mathrm{N}=64$ (60) pada taraf kesalahan $5 \%$ adalah 0,254 , sehingga $r_{\text {hitung }}>r_{\text {tabel }}(0,624>0,254)$.

Berdasarkan pemaparan-pemaparan tersebut, hal ini menunjukkan minat baca dan hubungan sosial harus ditingkatkan agar kompetensi pengetahuan IPS siswa optimal sehingga mampu beradaptasi dan memiliki pandangan luas terhadap suatu hal baik mengenai pelajaran maupun bermasyarakat.

\section{Simpulan}

Berdasarkan penelitian yang telah dilakukan maka dapat diketahui bahwa terdapat pengaruh yang signifikan minat baca terhadap kompetensi pengetahuan IPS pada siswa kelas V SD Gugus Dewi Sartika Kecamatan Denpasar Selatan hasil analisis ini menunjukkan bahwa minat baca memberikan kontribusi sebesar 3,7\% terhadap kompetensi pengetahuan IPS, dengan persamaan regresi $\widehat{Y}=19,091+0,338 X$ sehingga semakin meningkat minat baca maka akan meningkat pula kompetensi pengetahuan IPS. Dengan hasil ini maka masih terdapat 96,3\% faktor lainnya yang mempengaruhi kompetensi pengetahuan IPS pada siswa kelas V SD Gugus Dewi Sartika Kecamatan Denpasar Selatan disebabkan baik faktor dari dalam diri maupun faktor dari luar diri.

Terdapat pengaruh yang signifikan hubungan sosial terhadap kompetensi pengetahuan IPS pada siswa kelas V SD Gugus Dewi Sartika Kecamatan Denpasar Selatan dengan dilihat hasil analisis ini menunjukkan bahwa hubungan sosial memberikan kontribusi sebesar $4,6 \%$ terhadap kompetensi pengetahuan IPS, dengan persamaan regresi $\widehat{Y}=14,295+$ $0,398 \mathrm{X}$ sehingga semakin meningkat hubungan sosial maka akan meningkat pula kompetensi pengetahuan IPS. Dengan hasil ini maka masih terdapat 95,4 \% faktor lainnya yang mempengaruhi kompetensi pengetahuan IPS pada siswa kelas V SD Gugus Dewi Sartika Kecamatan Denpasar Selatan disebabkan oleh faktor belajar dari dalam diri maupun dari luar diri siswa.

Secara bersama-sama terdapat pengaruh yang signifikan minat baca dan hubungan sosial terhadap kompetensi pengetahuan IPS pada siswa kelas V SD Gugus Dewi Sartika Kecamatan Denpasar Selatan dapat dilihat pada uji $\mathrm{F}$ pada taraf signifikansi menunjukkan bahwa Fhitung $=4,63$ lebih dari $F$ tabel $=3,06$. Hasil analisis menunjukkan bahwa minat baca dan hubungan sosial secara bersama-sama memberikan kontribusi sebesar 5,9\% terhadap kompetensi pengetahuan IPS, dengan persamaan regresi $\widehat{Y}=2,330+0,215 X+$ $0,302 \mathrm{X}$ sehingga semakin meningkat minat baca dan hubungan sosial maka akan meningkat pula kompetensi pengetahuan IPS. Dengan hasil ini maka masih terdapat 94,1\% lainnya yang mempengaruhi kompetensi pengetahuan IPS pada siswa kelas V SD Gugus Dewi Sartika Kecamatan Denpasar Selatan disebabkan oleh faktor lain.

Maka dapat disimpulkan bahwa Minat baca mempengaruhi kompetensi pengetahuan IPS siswa pada kelas V SD Gugus Dewi Sartika Kecamatan Denpasar Selatan dengan kontribusi sebesar 3,7\%, Hubungan sosial mempengaruhi kompetensi pengetahuan IPS siswa pada kelas V SD Gugus Dewi Sartika Kecamatan Denpasar Selatan dengan kontribusi sebesar $4,6 \%$ serta secara bersama-sama kontribusi minat baca dan hubungan sosial terhadap kompetensi pengetahuan IPS menunjukkan terdapat pengaruh yang signifikan 
minat baca dan hubungan sosial terhadap kompetensi pengetahuan IPS pada siswa kelas $\mathrm{V}$ SD Gugus Dewi Sartika Kecamatan Denpasar Selatan kontibusi sebesar 5,9\%. Sedangkan sisanya $94,1 \%$ lainnya dipengaruhi oleh faktor belajar lainnya baik dari dalam diri berupa motivasi belajar, motivasi berprestasi, kecerdasan interpersonal, kecerdasan emosional, kecerdasan naturalis, konsep diri, disiplin belajar, sikap tanggungjawab, sikap kompetitif dan lain-lain serta faktor dari luar diri seperti fasilitas belajar, lingkungan pertemanan, gaya belajar, status anak dalam keluarga, pola asuh orang tua, bimbingan belajar, status ekonomi keluarga, lingkungan belajar dan kurikulum.

Berdasarkan hasil dan simpulan sebelumnya, sebagai tindak lanjut dari hasil tersebut maka penelitian ini disarankan bagi siswa, guru, kepala sekolah dan peneliti lain. Bagi siswa agar dapat memperkuat minat baca siswa dan hubungan sosial sehingga memiliki wawasan yang luas dan menjadi pribadi yang bisa memposisikan diri di masyarakat, serta leluasa dalam mengeluarkan pendapatnya ketika beriskusi di dalam kelas sehingga akan lebih mudah dalam meingkatkan kompetensi pengetahuan IPS di sekolah.

Bagi guru agar dapat dijadikan masukan bahwa apabila ingin meningkatkan kompetensi pengetahuan IPS siswa dapat dilakukan melalui peningkatan pada minat baca dan hubungan sosial siswa. Karena kompetensi pengetahuan IPS dipengaruhi oleh minat baca dan hubungan sosial sehingga guru dapat menciptakan kegiatan pembelajaran yang menugaskan dan melibatkan siswa lebih banyak untuk membaca dan berdiskusi dalam pembelajaran terutama kompetensi pengetahuan IPS.

Bagi kepala sekolah untuk pertimbangan dalam mengambil keputusan dan menentukan kebijakan agar kebijakan tersebut dapat mendukung kegiatan pembelajaran guru yang dapat menumbuhan minat baca dan hubungan sosial siswa dalam kompetensi pengetahuan IPS, menciptakan atau memperbaiki fasilitas-fasilitas sekolah yang dapat mengoptimalkan minat baca dan hubungan sosial siswa contohnya penataan kembali perpustakaan dan program membaca 1 minggu satu buku misalnya.

Hasil penelitian ini dapat dijadikan sebagai referensi bagi peneliti lain yang melaksanakan penelitian relevan mengenai minat baca dan hubungan sosial terhadap kompetensi pengetahuan IPS untuk lebih mendalami objek penelitiannya.

\section{Daftar Rujukan}

Agung, AA. Gede. 2006. Evaluasi Pendidikan. Singaraja: Institut Keguruan dan IImu Pendidikan Negeri.

Agung, AA. Gede. 2011. Pengantar Evaluasi Pendidikan. Singaraja: Institut Keguruan dan Ilmu Pendidikan Negeri.

Agung, AA. Gede. 2014. Metodelogi Penelitian Pendidikan. Malang: Aditya Media Publising.

Agung, AA. Gede. 2016. Statistika Dasar untuk Pendidikan. Yogyakarta: Deepublish.

Andriani, Durri. 2011. Metode Penelitian. Jakarta: Universitas Terbuka.

Arikunto, Suharsimi. 2015. Dasar-dasar Evaluasi Pendidikan. Jakarta: Bumi Aksara.

Candra,Wayan. 2016. Psikologi:Laandasan Keilmuan Praktik Keperawatan Jiwa. Denpasar: Politeknik Kesehatan Denpasar.

Dalman, H. 2013.Keterampilan Membaca.Jakarta: Rajawali Pers.

Dantes, Nyoman. 2012. Metode Penelitian. Yogjakarta:Andi Offset.

Darmadi, Hamid. 2014. Metode Penelitian Pendidikan. Bandung: Alfabeta 
Djaali, Haji. 2014. Psikologi Pendidikan. Jakarta: Bumi Aksara

Emzir. 2012. Metodelogi Penelitian Pendidikan. Jakarta: PT. Raja Grafindo, Persada.

Listriana, Desi. 2016. Hubungan Interaksi Sosial Siswa dengan Hasil Belajar IPS Kelas IV SDN Gugus Dewi Kunthi Kecamatan Gunungpati Kota Semarang. Skripsi. Pedidikan Guru Sekolah Dasar, Fakultas Ilmu Pendidikan, Universitas Negeri Semarang. 161 Halaman, Di akses pada tanggal: 14 November 2018.

Mulyasa. 2006. Kurikulum Berbasis Kompetensi. Bandung: PT. Remaja Rosdakarya

Naim, Ngainun. 2013. The Power of Reading. Yogyakarta: Aura Pustaka.

Permendikbud. 2016. Peraturan Menteri Pendidikan dan Kebudayaan Republik Indonesia Nomor 21 Tahun 2016 Tentang Standar Isi Kurikulum 2013 Pada Pendidikan Dasar dan Pendidikan Menengah. Jakarta: Kementerian Pendidikan dan Kebudayaan. Di akses tanggal: 5 Januari 2019

Permendikbud. 2014. Peraturan Menteri Pendidikan dan Kebudayaan Republik Indonesia Nomor 57 Tahun 2014 Tentang Kurikulum 2013 Sekolah Dasar/Madrasah Ibtidaiyah. Jakarta: Kementerian Pendidikan dan Kebudayaan. di akses tanggal: 5 Januari 2019

Purnomo, Rochmat Aldy. 2016. Analisis Statistik Ekonomi dan Bisnis dengan SPSS. Ponorogo: WAGE Group.

Rahim, Farida.2011.Pengajaran Membaca di Sekolah Dasar.Jakarta: PT. Bumi Aksara.

Rimbawan, Nyoman Dayuh. 2013.Statistik Inferensial Untuk Ekonomi dan Bisnis. Denpasar: Udayana University Press.

Riduwan dan Akdon. 2013. Rumus dan Data dalam Aplikasi Statistika. Bandung: Alfabeta.

Santosa, Slamet. 2006. Dinamika Kelompok. Jakarta: PT. Bumi Aksara.

Sanjaya, Wina. 2013. Penelitian Pendidikan. Jakarta: Prenada Media Grup.

Sari, Jeani Nurdiana. 2016. Hubungan antara Minat Baca dengan Hasil Belajar IPS Siswa Kelas V SD Negeri di Kecamatan Mijen Kota Semarang. Skripsi. Jurusan Pendidikan Guru Sekolah Dasar, Fakultas IImu Pendidikan Universitas Negeri Semarang. Diakses pada tanggal: 14 November 2018

Sayomukti, Nurani. 2016. Pengantar Sosiologi. Jogjakarta: Ar-Ruzz Media

Setyosari, Punaji. 2012. Metode Penelitian dan Pengembangan. Jakarta: Kencana.

Soekanto, Soerjono. 2010. Sosiologi Suatu Pengantar. Jakarta: Rajawali Pers.

Sudarsana, Undang. 2014. Pembinaan Minat Baca. Tanggerang Selatan: Universitas Terbuka.

Sugiyono. 2013. Statistik Untuk Penelitian. Bandung: Alfabeta

Sugiyono. 2015. Metode Penelitian Pendidikan. Bandung: Alfabeta

Sugiyono. 2017. Metodelogi Penelitian Pendidikan. Bandung: Alfabeta. 
Sugiyono. 2017. Statistik Untuk Penelitian. Bandung: Alfabeta

Sukardi. 2003. Metodologi Penelitian Pendidikan. Jakarta: Bumi Aksara.s

Supardi. 2013. Aplikasi Statistika Dalam Penelitian Edisi Revisi Konsep Statistika yang Lebih Komprehensif. Jakarta: Change Publication.

Suprihatiningrum, Jamil. 2016. Strategi Pembelajaran: Teori \& Aplikasi. Jogjakarta: Ar-Ruzz Media

Susanto, Ahmad. 2014. Teori Belajar dan Pembelajaran Di Sekolah Dasar. Edisi Pertama. Jakarta: Kencana Prenadamedia Group.

Susanto, Ahmad. 2014. Perkembangan Pembelajaran IPS Di Sekolah Dasar. Jakarta: Kencana Prenadamedia Group.

Undang-Undang. 2003. Undang-Undang Republik Indonesia Nomor 20 Tahun 2003 Tentang Sistem Pendidikan Nasional. Jakarta: Dewan Perwakilan Rakyat Republik Indonesia dan Presiden Republik Indonesia. di akses tanggal: 27 Desember 2018

Usman, Husaini dan Purnomo Setiady Akbar. Pengantar Statistika. Jakarta: Bumi Aksara.

Yanto, Juli. 2010.Hubungan Sosial Asosiatif dan Disosiatif. Bogor: PT. Regina Eka Utama.

Yusuf, Muri. 2015. Asesmen Dan Evaluasi Pendidikan. Jakarta: Prenada Media Group 